\title{
Erratum: A reply to community genetics: 1998-2009... and beyond
}

\author{
Ron L. Zimmern
}

Published online: 26 November 2010

(C) Springer-Verlag 2010

Erratum to: J Community Genet

DOI 10.1007/s12687-010-0019-8

\section{PUBLISHER'S ERRATUM}

Unfortunately Ron Zimmern's reply (10.1007/s12687-0100019-8) to Dirk Stemerding's Commentary (10.1007/ s12687-010-0018-9) had by mistake been filed under the section "Editorial". We are very sorry for that, because Dr. Zimmern's reply doesn't express the Editors-in-Chief's opinion, but solely his own, and therefore should have been labled as "Correspondence" instead of "Editorial".

We sincerely apologize for any inconvenience.

The Publisher

The online version of the original article can be found at http://dx.doi. org/10.1007/s12687-010-0019-8.

R. L. Zimmern $(\bowtie)$

Foundation for Genomics and Population Health,

Cambridge, UK

e-mail: ron.zimmern@phgfoundation.org 